\title{
人工膝関節置換術における肥満度の影響
}

\author{
泉 政 寛* 宮 崎 真 樹* 井 手 衆 哉* \\ 馬 渡 正 明* 佛 淵 孝 夫*

\section{Effect of Body Mass Index in \\ Total Knee Arthroplasty}

\begin{abstract}
Masahiro Izumi*, Masaki Miyazaki*, Shuuya Ide*, Masaaki Mawatari*, and Takao Hotokebuchi*
\end{abstract}

\begin{abstract}
当院にて 2006 年 1 月から 2009 年 1 月までに行った TKA 294 例 444 膝を対象とし, 術後合併症や術前 後の膝関節機能と患者の肥満度との関連性を検討した。 これらの患者を BMI を用いて 3 群に分類し，そ れぞれの年齢，既往歴，合併症，膝関節機能，術後在院日数を調べた．全症例の BMI の平均は 25.7 であ り，BMI 30 以上の高度肥満群は 46 例 $(15.6 \%)$ であった。年齢，在院日数，膝関節機能は各群間で有 意差を認めなかった，術前の糖尿病の既往，術後合併症の総数（術創に関する合併症）は高度肥満群で有 意に多い結果となった，TKA において，肥満患者も非肥満患者と同様の手術の成果を得ることはできた が，手術に関して合併症などの問題点があることを十分説明する必要があると考えられた.
\end{abstract}

We evaluated the association between postoperative complications and knee joint function and degree of obesity in 294 TKA patients (444 knees) at our hospital from January 2006 to January 2009. The patients were grouped into three weight classes according to bodymass index. Patient age, medial history, complications, knee joint function, length of hospital stay were recorded.

The average BMI of all cases was 25.7. The high BMI group (BMI $\geqq 30)$ cousisted of 46 cases $(15.6 \%)$. No significant difference was seen in age, hospitalization days, knee joint function between the groups.

The high BMI gruop showed history of diabetes preoperativery and high rate of complications (wounds complication).

Through TKA, high BMI the corpulence patients were able to achieve the same surgical results as 10w BMI patients, but surgical complications need to be taken into consideration.

Key words : total knee arthroplasty (人工膝関節置換術), body mass index (BMI), complications (合併症), obesity（肥満）

\section{I.はじめに}

肥満は，変形性関節症や膝の半月板損傷と関連があ るとされている゙.

それゆえ，日常診療において変形性膝関節症の患者 のなかに肥満患者を見かける機会は多くある. 変形性 膝関節症に対して人工膝関節全置換術（以下 TKA） は有用な治療法の 1 つであり, TKA が行われる患者 には肥満患者の割合が高い.
今回，当院で行った TKA 患者の肥満度と周術期の 状態（術前既往歴，術後合併症）や術前後の膝関節機 能について調査した。

\section{II. 対象と方法}

2006 年 1 月から 2009 年 1 月までの 3 年間に当院で 行ったTKA 294 例 444 膝を対象とした.

対象患者の手術時年齢は平均 72.9 歳（28～94 歳）, 原疾患の内訳は，変形性関節症（以下 $\mathrm{OA} ２ 60$ 例

\footnotetext{
* 佐賀大学整形外科 Department of Orthopedic Surgery, Faculty of Medicine, Saga University, Saga, Japan
} 
396 膝，関節リウマチ 28 例 40 膝，骨壊死 4 例 6 膝, 外傷, Charcot 関節がそれぞれ 1 例 1 膝であつた.

男女別内訳では女性 237 例（81\%），男性 57 例（19 \%) と女性に有意に多く認め, 対象患者の平均 BMI は2 5.7 (13.3〜 40.2）であった. また平均術後経過観 察期間は 17.8 ケ月であった.

これらの患者の BMI を用いて，A 群（標準体型群）：

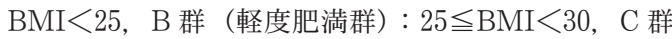
(高度肥満群)：BMI $\geqq 30$ の 3 群に分類した. A 群は 135 例，B群は 113 例，C 群は 46 例であった。それ ぞれの群において，年齢，術後の経過観察期間に有意 な差は認めなかった（表 1).

今回，これら 3 群において 1）術前既往歴 2）術後 合併症 3）術前後の膝関節機能を比較した.

術前後の膝関節機能評価として, Knee Society Score $^{5)}$ の Knee score と Functional score を用いた。

表 1 各群の患者背景

\begin{tabular}{ccccc}
\hline \hline & $\begin{array}{c}\text { Group A } \\
(\mathrm{n}=135)\end{array}$ & $\begin{array}{c}\text { Group B } \\
(\mathrm{n}=113)\end{array}$ & $\begin{array}{c}\text { Group C } \\
(\mathrm{n}=46)\end{array}$ & P value \\
\hline 年 齢 & 72.7 & 73.2 & 72.4 & n.s. \\
経過観察期間(月) & 18.1 & 18.4 & 15.5 & n.s. \\
\hline
\end{tabular}

\section{III. 結}

\section{果}

1 ）術前既往歴（表 2)

術前の既往歴において，高血圧症の既往はいずれの 群でも多く認められ，A 群 79 例 $(58.5 \%) ， \mathrm{~B}$ 群 61 例 $(54.0 \%) ， \mathrm{C}$ 群 34 例 $(73.9 \%)$ であった。 3 群間 に有意な差は認めなかったものの C 群でより多く認

表 2 各群間の主な術前既往歴 $(n=294)$

\begin{tabular}{llll}
\hline \hline & $\begin{array}{c}\text { Group A } \\
(\mathrm{n}=135)\end{array}$ & $\begin{array}{c}\text { Group B } \\
(\mathrm{n}=113)\end{array}$ & $\begin{array}{c}\text { Group C } \\
(\mathrm{n}=46)\end{array}$ \\
\hline 高血圧症 & 79 & 61 & 34 \\
糖尿病 & $11(8.1 \%)$ & $14(12.4 \%)$ & $11(23.9 \%){ }^{*}$ \\
心血管障害 & 7 & 10 & 3 \\
心不全 & 4 & 1 & 0 \\
不整脈 & 14 & 11 & 9 \\
脳血管障害 & 9 & 9 & 4 \\
腎不全 & 6 & 1 & 1 \\
喘息 & 8 & 3 & 3 \\
\hline & & & ${ }^{*} \mathrm{P}<0.05$
\end{tabular}

められる傾向であつた.

糖尿病の既往歴は A 群 11 例 (8.1\%)，B 群 14 例 (12.4\%)，C 群 11 例（23.9\%）で有意に C 群で多く 認める結果となった $(\mathrm{p}<0.05)$.

その他，主な既往歴で 3 群間に有意な差は認めなかつ た.

2 ) 術後合併症（表 3)

術後, 主な合併症として深部静脈血栓症, 肺塞栓症, 術創治癒遅延，貧血，感染，心不全などを認めた．肥 満患者において riskが高いとされている深部静脈血 栓症（DVT), 肺塞栓症（PE）は 3 群間で差は認め られなかった。

術創の治癒遅延は A 群 5 例 (3.7\%), B 群 3 例 (2.7 \%)，C 群 6 例（13.0\%）に認め，C 群で有意に術創 の治癒が遷延する患者が多く認められた $(\mathrm{p}<0.05)$.

また，主な術後合併症の総数も $\mathrm{C}$ 群で有意に多く 認められた $(\mathrm{p}<0.01)$.

表 3 各群間の主な術後合併症 $(\mathrm{n}=294)$

\begin{tabular}{llll}
\hline \hline & $\begin{array}{c}\text { Group A } \\
(\mathrm{n}=135)\end{array}$ & $\begin{array}{c}\text { Group B } \\
(\mathrm{n}=113)\end{array}$ & $\begin{array}{c}\text { Group C } \\
(\mathrm{n}=46)\end{array}$ \\
\hline 深部静脈血栓症 & 5 & 8 & 3 \\
肺塞栓症 & 1 & 1 & \\
術創治癒遅延 & $5(3.7 \%)$ & $3(2.7 \%)$ & $6(13.0 \%)^{*}$ \\
貧血 & 6 & 1 & 4 \\
感染 & 2 & 5 & 3 \\
心不全 & 0 & 4 & 1 \\
不整脈 & 1 & 2 & 0 \\
脳梗塞 & 0 & 1 & 0 \\
腎不全 & 1 & 1 & 0 \\
計 & $21(15.6 \%)$ & $26(23.0 \%)$ & $17(37.0 \%)^{* *}$ \\
\hline & & \multicolumn{2}{c}{${ }^{*} \mathrm{p}<0.05{ }^{* *} \mathrm{p}<0.01$}
\end{tabular}

3 ) 術前後 Knee score（図 1-1）

術前 Knee score は A 群で 40.5 点, B 群で 39.4 点, $\mathrm{C}$ 群で 35.8 点であり, 肥満度が高くなるにつれて点 数が低くなる傾向は認めたが，有意な差は認めなかつ た.

術後 Knee score は A 群で 91.2 点, B 群で 89.0 点, C 群で 88.1 点といずれの群でも大幅な改善を認め, また 3 群間の差も認められなかった.

3 ) 術前後 Functional score（図 1-2)

術前 Functional score はA 群で 29.6 点, B 群で 
$(\mathrm{N}=294)$

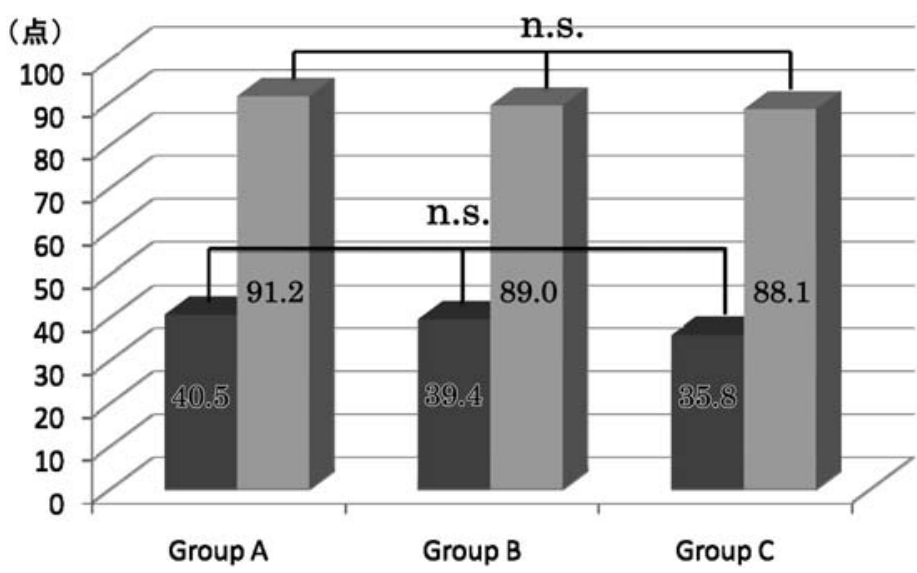

口術前

術後

図 1-1 各群間の術前後の Knee score の結果 $(n=294)$

（N=294）

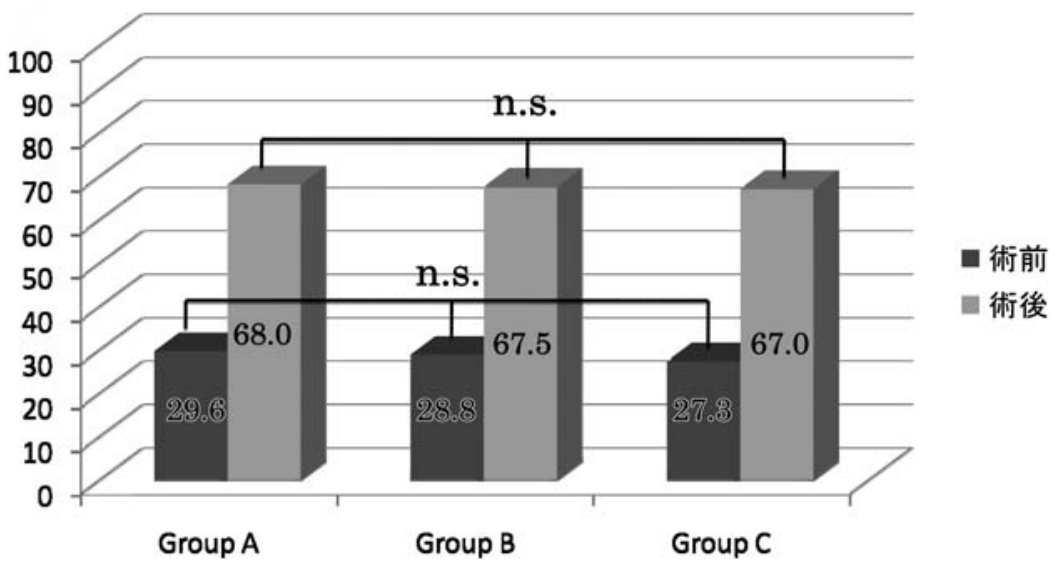

図 1-2 各群間の術前後の Functional score の結果 $(\mathrm{n}=294)$

28.8 点, C 群で 27.3 点であり, Knee score と同様に 肥満度が高くなるにつれて点数は低くなる傾向であつ たが, 有意な差は認めなかった. 術後 Functional score はA 群で 68.0 点, B 群で 67.5 点, C 群で 67.0 点といずれの群でも改善を認め, 3 群間の差は認めら れなかつた.

$$
\text { IV. 考察 }
$$

(1)肥満は関節疾患に関連があり, 膝の関節疾患を持つ た女性の $70 \%$, 男性の $35 \%$ が体重過多という報告が
ある1). (3) TKA は変形性膝関節症に対する有用な治 療法の 1 つとされており, それゆえTKA 治療を受け る患者に肥満患者の割合は多い. (4)今回, 当院にて TKA をおこなった患者の 54\%（女性 54\%，男性 53 \%) が BMI 25 以上の体重過多であり，(2)肥満は既 往症も多く, 具体的には高血圧症, 糖尿病, 脳血管障 害が関連あるとされている ${ }^{9)}$. (5)肥満患者は高血圧症 や糖尿病の既往が多くみられ諸家の報告と同様の結果 であった. TKA 後に肥満患者は合併症を起こすこと が多いとされ5)，特に DVT や PE と肥満患者との関 
連を報告した文献は多く認められる26).

また，術創に関する合併症（術創感染症，術創治癒 遅延）に関しても報告されている．本研究では DVT/ $\mathrm{PE}$ や術創感染は肥満患者で多く認められなかったが, 術創の治癒遅延は有意に肥満患者で多く認められ，肥 満が術創に何らかの影響を与えていることが考えられ た。術創に関するトラブルが肥満患者に多いのは，肥 満患者の免疫反応が弱く, 血管組織が脆弱化している からだといわれている ${ }^{11)}$. Krishnan らは試験管試験 にて肥満患者はマクロファージに分化する単球の数が 少ないこと ${ }^{8}$, Kolterman らは肥満患者が非肥満患者 と比べてリンパ球遊走阻止因子が多い ことを報告し ており，これらの原因として肥満患者と強く関連のあ るインスリン抵抗性や高血糖状態が白血球機能を阻害 するとされている.

最近の研究では, 肥満患者と非肥満患者の術後膝関 節機能は術後 2 年間では差がない童 と報告されており, Mont らも 65 ヶ月の経過で有意な差は出なかったと 報告している ${ }^{10)}$. 当院の結果においても, 経過観察期 間は 18 ヶ月ではあるが膝関節機能は肥満患者も非肥 満患者と同様の満足な結果を得られていた。しかし， Griffin らは 10 年以上の長期成績では肥満患者の腮 関節機能は有意に低下すると報告している は短期成績であり体重過多によるインプラントストレ スを考えると, 今後も追跡調査が必要である.

今回，当院の研究において，肥満患者は非肥満患者 と比較すると術前の既往歴は多く, 術後の合併症も多 く認める結果であったが, 術後の膝関節機能は同様に 改善しており TKA において肥満患者も満足のいく結 果を得られていると考えられた。

$$
\text { V. 結語 }
$$

(1)当院にて人工膝関節置換術を行つた TKA 294 例 444 膝の肥満度と周術期合併症や膝関節機能を比較検
討した.

(2)肥満患者は非肥満患者と比較し，糖尿病や高血圧 症の既往歴や術後合併症を多く認めたが，術後膝関節 機能は同様の満足度が得られた。

\section{参 考 文 献}

1) Bray, G. A.: Complications of obesity. Ann. Intern. Med., $103:$ 1052-1062, 1985.

2) Dorr, L. D., et al.: Fat emboli in bilateral total knee arthroplasty. Predictive factors for neurologic manifestations. Clin. Orthop. Relat. Res., 248 : 112118, 1989

3) Ersozlu, S., et al.: Bilateral staged total knee arthroplasty in obese patients. Arch. Orthop. Trauma Surg., $128:$ 143-148, 2008.

4) Griffin, F. M.: Total knee arthroplasty in patients who were obese with 10 years follow-up. Clin. Orthop. Relat. Res., 356 : 28-33, 1998.

5) Insall, J. N., et al.: Rationale of the Knee Society clinical rating system. Clin. Orthop. Relat. Res., $248: 13-14,1989$.

6) Jankiewicz, J. J., et al.: One-stage versus 2-stage bilateral total knee arthroplasty. Clin. Orthop. Relat. Res., 309 : 94-101, 1994.

7) Kolterman, O. G., et al.: A defect in cell-mediated in function in insulin-resistant diabetic and obese subjects. J. Lab. Clin. Med., 96 : 535-543, 1980.

8) Krishnan, E.C., et al.: Study of function and maturation monocytes in morbidly obese individuals. J. Surg. Res., $33:$ 89-97, 1982.

9) Miric, A., et al.: Perioperative morbidity following total knee arthroplasty among obese patients. J. Knee Surg., 15(2) : 77-83, 2002

10) Mont, M. A., et al.: Cementless total knee arthroplasty in obese patients. A comparison with a matched control group. J. Arthroplasty, 11(2) : 153156,1996

11) Winiarsky, R., Barth, P., Lotke, P.: Total knee arthroplasty in morbidly obese patients. J. Bone Joint Surg., 80 : 1770-1774, 1998. 